\title{
Ledstilling i ledsætninger i dansk som arvesprog i Argentina. Et foreløbigt studium
}

\section{Anna Sofie Hartling}

This paper presents a case study of word order variation in subordinate clauses (henceforth 'subclauses') in Heritage Danish in Argentina. In European Danish, the placement of the sentence adverbial traditionally distinguishes so-called main clause word order (conj $>\mathrm{S}>\mathrm{Vfin}>\mathrm{Adv})$ and subclause word order (conj $>\mathrm{S}>\mathrm{Adv}>\mathrm{Vfin})$. The paper shows that this normative distinction still holds in more than half of the subclauses in Heritage Danish in Argentina, and, except for the relative clauses, to an even higher degree than in colloquial European Danish. Hence, the word order distribution in Heritage Danish also differs from Heritage Norwegian and Swedish where word order in subclauses has become optional due to incomplete acquisition of the heritage language.

Nøgleord: ledstilling, ledsætninger, variation, arvesprog, sprogkontakt, dansk/spansk

\section{Indledning}

Ledstilling i ledsætninger - og især 'helsætningsledstilling' i ledsætninger som et af mange eksempler på et 'helsætningsfænomen' ('Main Clause Phenomenon, MCP') - er i de senere år i vidt omfang blevet udforsket i de skandinaviske sprog. Fokus har især været på hvad der forudsætter at 'helsætningsledstilling' eller V2 kan forekomme i en underordnet sætningskontekst ('indlejret V2'), og hvilken effekt det har når det sker. Mange af undersøgelserne er formelle

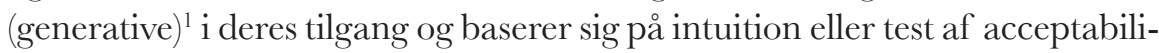

1 Fra generativt hold har man bl.a. diskuteret det standpunkt som har været gældende i årtier: at man ikke kan flytte et led ud af en underordnet sætning med V2 (Andersson 1975, de Haan \& Weermann 1986). Julien (2008:168) viser at det er muligt for norsk- og svensktalende (her de svenske eksempler): "Den här artikeln sade hon at hon fick inte tid att läsa" - og også med faktive prædikater i hovedsætningen: "Den här artikeln glömde hon att hon hade redan läst". 
tet, og mange beskæftiger sig (fortrinsvis) med skriftsprog. En meget væsentlig undtagelse herfra udgør Jensen \& Christensens omfangsrige undersøgelse af $\mathrm{V}>\operatorname{adv}(\mathrm{V} 2)$ hhv. adv $>\mathrm{V}(\mathrm{V} 3)$ i ledsætninger i dansk talesprog hos talere fra tre generationer og fra to steder i Danmark (Vinderup i Jylland og København) (se fx Jensen \& Christensen 2013; Christensen \& Jensen 2014a, 2014b).

I denne artikel fremlægger jeg en undersøgelse af ledstilling i ledsætninger hos fire dansktalende efterkommere til danskere der udvandrede til Argentina mellem ca. 1850 og $1930 .^{2}$

\subsection{Dansk-argentinerne som arvesprogstalere og dansk $i$ Argentina som arvesprog}

Kun en relativt lille del af de mange tusinde efterkommere til de danske udvandrere i Argentina i dag taler og/eller forstår dansk, og vi kan konstatere at dansk som arvesprog er ved at forsvinde i Argentina. Men skønt det på den ene side er på retur, er det på den anden side ualmindelig velbevaret, både set i forhold til hvor mange år siden udvandringen fandt sted og sammenlignet med dansk i USA.

De efterkommere af danske udvandrere der taler og/eller forstår dansk i dag i 2., 3., 4. og helt op til 5. generation, passer godt på definitionen af arvesprogstalere, 'heritage speakers', som den fx er formuleret hos Polinsky (2011):

A heritage speaker is a bilingual who grew up hearing and possibly speaking an immigrant language or a minority language as a home language, and who has been dominant in the majority language of the wider community at least since early childhood. (2011:306).

Et arvesprog, 'heritage language', er altså et minoritets- eller immigrantsprog som er tilegnet på en "naturlig" måde, men som kan være karakteriseret af at inputtet kvanti- og kvalitativt er mere begrænset end det der gælder for tilegnelsen af et førstesprog i monolingvale situationer. Desuden er det ofte påvirket af det omgivende samfunds majoritetssprog og den manglende skoling i og på sproget. Derudover er der tale om sprog med kulturel betydning for den gruppe af mennesker med fælles oprindelse der er vokset op med det (Polinsky \& Kagan 2007; Benmamoun et al. 2013). Et arvesprog er først et

2 Jeg har foretaget undersøgelsen i forbindelse med mit ph.d.-projekt om dansk i Argentina. Mit projekt er indlejret i et større forskningsprojekt, 'Danske stemmer i USA og Argentina', ved Københavns Universitet. 
arvesprog når det nedarves hos andengenerationsimmigranterne. De arver det fra deres forældre, dvs. førstegenerations-immigranterne, hvis variant af sproget kaldes for 'baseline'.

Forskningsfeltet 'heritage linguistics' er forholdsvis nyt i Danmark skønt det i Nordamerika - og til dels i det øvrige Skandinavien - har eksisteret som sådan i flere årtier.

På grund af de sociokulturelle fællestræk ved arvesprog (skitseret ovenfor) hersker der inden for 'heritage linguistics' en antagelse om at arvesprog også deler en række grammatiske og fonetiske træk som adskiller dem fra både L1 - og L2-sprog. Ud over at finde frem til disse ligheder på tværs af arvesprogene går bestræbelserne i høj grad på at bestemme om det enkelte sproglige særtræk skyldes afbrudt tilegnelse ('incomplete acquisition'), sprogsvækkelse ('attrition'), kontakt med det dominerende sprog ('transfer') eller evt. sprogintern forandring ('drift').

Formålet med denne artikel er at fremlægge de første resultater af en undersøgelse af om distributionen af $\mathrm{V}>\mathrm{adv}-\mathrm{og} \mathrm{adv}>\mathrm{V}$-ledstilling i ledsætninger i arvesprogsvarieteten afviger fra den man finder i danmarksdansk talesprog. Videre studier vil vise om eventuelle afvigelser på dette punkt og i forhold til andre morfosyntaktiske træk skyldes afbrudt tilegnelse, sprogsvækkelse eller kontakten med spansk. Selve kontaktsituationen kan både have ført til strukturer der er konvergeret mod spansk, og strukturer der ikke er konvergeret mod spansk. Sidstnævnte kan betegnes kontaktinduceret nonkonvergens, og en mulig konsekvens heraf er at strukturer som de to sprog har til fælles, bliver konserveret og mere stabile i minoritetssproget, på bekostning af andre mulige semantiske ækvivalenter (Kaufman 2010: 481).

\section{Udgangspunkt for casestudiet}

Benmamoun et al. (2013:148) angiver at syntaks, herunder ledstilling, ikke er så sårbart som fx bøjningsmorfologi over for en tilegnelse der mere eller mindre afbrydes hos arvesprogstalere i form af reduceret input. Flere studier af ledstilling blandt arvesprogstalere med skandinaviske og islandske rødder tyder dog på at det er et felt der udviser stor variation (se fx Flodell 1996; Kühl 2014; Arnbjörnsdóttir 2015; Eide \& Hjelde 2015; Larsson \& Johannessen 2015a;2015b).

Netop Larsson \& Johannessens (2015a; 2015b) arbejde om ledstilling i norsk og svensk arvesprog i USA er en af kilderne til grundantagelsen i det casestudie, jeg præsenterer her, om at fordelingen af ledsætnings- og helsætnings- 
ledstilling (herefter adv $>V$ - og V >adv-ledstilling) i ledsætninger i talt dansk i Argentina er forskellig fra det mønster man finder i danmarksdansk talesprog. De finder overordnet set at normafvigelserne i ledstillingen i ledsætninger i norsk og svensk i USA er så store at man kan tale om at en forandring har fundet sted i syntaksen i svensk og norsk arvesprog. Samtidig konkluderer de at denne forandring ikke skyldes kontakten med majoritetssproget engelsk, men derimod 'afbrudt tilegnelse' af arvesproget (jf. afsnit 2.2.). Det gør det oplagt at undersøge om en parallel udvikling har fundet sted i dansk i Argentina.

Men i første omgang er antagelsen om at der er en forskel på ledstillingsfordelingen i ledsætninger i dansk i Danmark og dansk i Argentina, baseret på data hvor man fx kan observere flere forekomster af attributive ledsætninger med V >adv-ledstilling. Dette forekommer sjældent i danmarksdansk (jf. afsnit 2.1.). Det er eksempler som (1):

(1) DOB: så der gik vi så i \# i skole \# de sidste \# femte og \# sexto grado som var jo \# dengang eksisterede! det ikke \#3

I det følgende gennemgår jeg kort ledstillingsmønstrene i ledsætninger i hhv. (moderne) danmarksdansk talesprog (baseret på bl.a. Jensen 2011; Jensen \& Christensen 2013; Christensen \& Jensen 2014a, 2014b) og talt svensk og norsk arvesprog i USA (baseret på Larsson \& Johannessen 2015a, 2015b).

\subsection{Ledstilling $\boldsymbol{i}$ ledsatninger $i$ danmarksdansk talesprog}

I ledsætninger i moderne danmarksdansk talesprog anvendes ikke kun den af standardnormen foreskrevne ledstilling i ledsætningsskemaet (jf. eksempel (4)). Jensen (2011) og Christensen \& Jensen (2014b) finder at omkring halvdelen af de ledsætninger der lader sig analysere i forhold til ledstilling, har V>adv-ledstilling. ${ }^{4}$ Det gælder for dansk at ledstillingen kun kan afgøres i de ledsætninger der indeholder et sætningsadverbial, SA, og Jensen \& Christensen (2013:39) konkluderer at man i det samlede antal ytrede ledsætninger derfor

3 På trods af sin ufuldstændighed lader den understregede ledsætning ikke nogen tvivl om ledstillingen og er derfor talt med.

4 Resultaterne bygger på en stor undersøgelse af udskrifter af 132 1-3 timer lange optagelser med 91 informanter fordelt på to geografiske steder, Vinderup i Vestjylland og København, og på tre aldersgrupper: Generation 1 (født i perioden 1942-63), Generation 2 (født i perioden 1964-1974) og Generation 3 (født 1989-92). Optagelserne udgør en del af LANCHART-korpusset. 
kun kan analysere $25 \%$. Når de inddeler ledsætningerne efter type, finder de følgende mønstre:

\begin{tabular}{|l|l|}
\hline Nominale ledsætninger & $\begin{array}{l}45 \% \text { V }>\text { adv-ledstilling; 64 \% når man inkluderer såkaldt } \\
\text { citerede og primære ledsætninger (Jensen \& Christensen } \\
2013: 48)\end{array}$ \\
\hline Adverbielle ledsætninger & $\begin{array}{l}60 \% \text { V }>\text { adv-ledstilling (Christensen, Jensen \& Christensen } \\
2015: 108)\end{array}$ \\
\hline Attributive ledsætninger & $4 \% \mathrm{~V}>$ adv-ledstilling (Jensen 2011:134) \\
\hline
\end{tabular}

I danmarksdansk talesprog er flere ledstillinger mulige i ledsætninger, men de tre hyppigste svarer til eksemplerne i (2), (3) og (4):

V>adv, 'helsætningsskema'

$\begin{array}{lllllll} & \text { K } & \text { X } & \text { Vfin } & \text { (S) } & \text { SA } & \text { (FV/FA) } \\ (2) & \text { at } & \text { han } & \text { spiste } & & \text { vist ikke } & \text { pasta i går } \\ (3) & \text { at } & \text { i går } & \text { spiste } & \text { han } & \text { vist ikke } & \text { pasta }\end{array}$

$\operatorname{adv}>V$, 'ledsætningsskema'

(4) at han vist ikkespiste pasta i går

Jensen \& Christensen (2013:51) og Christensen, Jensen \& Christensen (2015:112) påviser endvidere at konjunktionstypen spiller en stor rolle for hvilken ledstilling de nominale og adverbielle ledsætninger har, og de finder følgende fordeling:

- For de nominale ledsætninger gælder det at V>adv-ledstilling langt overvejende findes i at-ledsætninger eller ledsætninger uden nogen konjunktion, mens kun $8 \%$ af ledsætningerne med $h v$-ord eller om har $\mathrm{V}>$ adv-ledstilling.

- For de adverbielle ledsætninger er der V>adv-ledstilling i $89 \%$ af fordiledsætningerne og $63 \%$ af dem med implicit konjunktion, og kun i 9 $\%$ af ledsætningerne med andre typer konjunktioner.

Hvad angår det semantisk-pragmatiske aspekt ved valg af ledstilling i ledsætninger, har Christensen, Jensen og Christensen med deres undersøgelser 
kunnet bekræfte den hypotese, som er foreslået af bl.a. Heltoft (1999), om at $\mathrm{V}>$ adv-ledstillingen signalerer at den vigtigste information i sætningen skal findes i ledsætningen og ikke i oversætningen. V>adv-ledstilling forgrunder m.a.o. ledsætningen.

Vi kan af gode grunde ikke vide præcis hvordan ledstillingsfordelingen i ledsætninger var i det sprog som er baseline for arvesprogstalerne af dansk i Argentina i dag, dvs. dansk talesprog fra midten af det 19. århundrede til ca. 1930. Det nærmeste vi kan komme det, er Gregersen \& Pedersen (2001) der viser hvordan den typologiske distinktion mellem helsætning og ledsætning var konventionaliseret i skriftsproget omkring 1900. Samtidig viser de ved at sammenholde moderne talesprog med dialektalt talesprog at $\mathrm{V}>$ adv-ledstilling er et relikt i talesproget som aldrig helt har været forsvundet. Dialektalt har den stået stærkest i Jylland og på Fyn (Pedersen 1996). Vi kan altså konstatere at $\mathrm{V}>$ adv-ledstillingen også har været anvendt i ledsætninger i de år hvor danskerne udvandrede til Argentina. Vi ved blot ikke hvor udbredt denne anvendelse har været sammenlignet med hvor udbredt den er blandt danskere født mellem 1942 og 1992 (jf. Jensen \& Christensens undersøgelser). Det foreliggende casestudie er et skridt på vejen mod at finde ud af hvor på dette kontinuum dansk i Argentina befinder sig, og at finde frem til grundene til at det placerer sig der.

\subsection{Ledstilling $i$ ledsatninger $i$ norsk og svensk arvesprog $i \boldsymbol{U S A}$}

Som nævnt ovenfor er Larsson \& Johannessen (2015a, b) kommet frem til at der i norsk og svensk arvesprog i USA er sket en forandring i syntaksen i forhold til udgangspunktet, dvs. baseline. De finder V>adv-ledstilling i alle typer af ledsætninger, og de argumenterer på den baggrund for at "Heritage Scandinavian has optional V-to-T movement", og at denne "flytning" er uafhængig af ledsætningstype (2015a: p.172-3). De forklarer som nævnt forandringen i syntaksen hos arvesprogstalerne med "incomplete acquisition", altså at tilegnelsen er blevet afbrudt, og ekspliciterer samtidig at forandringen kun er indirekte afhængig af kontakten med engelsk: I takt med at engelsk bliver arvesprogstalernes primære og stærkeste sprog, afbrydes tilegnelsen af arvesproget.

Deres konklusioner bygger på at de finder V>adv-ledstilling i omtrent halvdelen af det samlede antal ledsætninger i arvesprogsdataene, mens "the verb generally follows negation" i relativsætninger, underordnede spørgsmål og betingelsessætninger i de data de har fra førstegenerationsindvandrere i 
USA (2015a:165). ${ }^{5}$ De plæderer i øvrigt for at dette baselinesprog har samme ledstillingssyntaks som de moderne europæiske varieteter af svensk og norsk (2015a:166). Med at-sætninger er det anderledes idet visse prædikater i oversætningen "tillader" V>adv-ledstilling i den efterfølgende at-sætning på baseline/moderne svensk og norsk, men Larsson \& Johannessen finder stadig en stor diskrepans mellem disse varieteter og arvesprogsvarieteterne: 50,6 \% af $a t$-sætningerne i den norske $\operatorname{del}^{6}$ af det såkaldte Nordic Dialect Corpus (jf. www.tekstlab.uio.no/nota/scandiasyn) har V>adv-ledstilling mod $94 \%$ i deres arvesprogsdata. De $94 \%$ dækker imidlertid over kun 15 eksempler (Larsson \& Johannessen 2015a:170; 2015b:245,250).

Hvad angår afbrudt tilegnelse som forklaringsfaktor, bygger Larsson \& Johannessen (2015a:175ff) det på studier der viser at også svenske og norske L1-lørnere (monolingvale børn), dvs. talere hvis tilegnelse endnu ikke er fuldendt, har valgfri ledstilling i ledsætninger. De konkluderer på det grundlag at ledstillingsvalgfriheden "appears to be a feature of incompletely acquired Scandinavian in general".

Larsson \& Johannessen finder i det de kalder 'Heritage Scandinavian' (svensk og norsk i USA), et nyt og forandret mønster i ledstillingen i ledsætninger, som de plæderer for, ikke skyldes transfer fra engelsk. Deres undersøgelse inspirerer til at forsøge at svare på om dette også gælder for et andet eksempel på 'Heritage Scandinavian', nemlig dansk i Argentina.

\section{Datamateriale og metode}

I løbet af tre feltarbejder i 2014 og 2015 har vi i projektet 'Danske Stemmer i Argentina' lavet optagelser med over 100 arvesprogstalere af dansk i Argentina. Den ældste informant er født i 1911, den yngste i 1971. Gennemsnitsalderen

5 Larsson \& Johannessens (2015a;b) kvantitative basis er meget lille: I alt indgår 32 ledsætninger med $\mathrm{K}=\mathrm{om} / \mathrm{som} /$ at $\mathrm{og} \mathrm{SA}=i k k$ for arvesprogsdelen og 54 ledsætninger med $\mathrm{K}=\mathrm{om} / \mathrm{som} /$ at $\mathrm{og} \mathrm{SA}=i k k e$ for baseline/moderne svensk og norsk. Desuden dækker den kvantitative del af analysen i realiteten kun det norske arvesprogskorpus da der endnu ikke fandtes transskriptioner af det tilsvarende svenske. Larsson \& Johannessen (2015b: 251) argumenterer for at deres resultater også gælder for svensk i USA da der er "no reason to assume that Heritage Swedish should be different from Norwegian, and it is easy to find examples of the verb-adverb order".

6 Kun data for norsk talesprog repræsenterer kvantitativt det som Larsson \& Johannessen kalder "European Scandinavian". Det har været nødvendigt eftersom også kun de norske arvesprogsdata analyseres kvantitativt (jf. note 5). 
for informanterne er ca. 75 år. Den aldersmæssige uligevægt i informantgruppen afspejler den faktiske fordeling i sprogkompetencen; vi er ikke stødt på nogen under 40 år der taler dansk aktivt, og kun de allerældste bruger det regelmæssigt. Vores data består først og fremmest af 60-90 minutter lange semistrukturerede interview med informanterne.

For at afprøve de hypoteser om ledstilling i ledsætninger i dansk i Argentina som jeg har opstillet for dette casestudie, har jeg udtaget fire interview med fire forskellige talere som har følgende karakteristika:

1) $\mathrm{ABO}$, mand, født 1933, interviewlængde: 01:17:25

\begin{tabular}{|l|l|}
\hline Sprog & $\begin{array}{l}\text { - dansk L1 } \\
\text { - spansk hen ad vejen }\end{array}$ \\
\hline I Danmark & - tre år på Sjælland (14-17 år) \\
\hline Skolegang & $\begin{array}{l}\text { - ingen offentlig skolegang i Argentina; undervist af mor (sammen } \\
\text { med nabolagets børn) }\end{array}$ \\
\hline Udvandring & $\begin{array}{l}\text { - far fra Sjælland, årstal ukendt } \\
\text { - mor fra Sjælland, årstal ukendt }\end{array}$ \\
\hline
\end{tabular}

2) CMK, kvinde, født 1935, interviewlængde: 01:35:30

\begin{tabular}{|l|l|}
\hline Sprog & $\begin{array}{l}\text { - dansk L1 } \\
\text { - spansk ved skolestart (5 år) }\end{array}$ \\
\hline I Danmark & - én gang i 1993 (ferie) \\
\hline Skolegang & - ingen offentlig undervisning på/i dansk \\
\hline Udvandring & $\begin{array}{l}\text { - far fra Fyn, årstal ukendt } \\
\text { - morforældre fra den nordøstlige del af Jylland, årstal ukendt }\end{array}$ \\
\hline
\end{tabular}

3) DOB, kvinde, født 1921, interviewlængde: 01:40:53

\begin{tabular}{|l|l|}
\hline Sprog & $\begin{array}{l}\text { - dansk L1 } \\
\text { - spansk ved skolestart (5 el. } 6 \text { år) }\end{array}$ \\
\hline I Danmark & - tre år i det midtøstlige Jylland (8-11 år) \\
\hline Skolegang & - ingen offentlig undervisning på/i dansk i Argentina \\
\hline Udvandring & $\begin{array}{l}\text { - far fra Sorø/København/Berlin i } 1874 \\
\text { - mor fra det midtøstlige Jylland i } 1891\end{array}$ \\
\hline
\end{tabular}

4) BEB, kvinde, født 1933, interviewlængde: 01:34:40

\begin{tabular}{|l|l|}
\hline Sprog & $\begin{array}{l}\text { - dansk L1 } \\
\text { - spansk ved skolestart (5 år) }\end{array}$ \\
\hline I Danmark & - én gang i 1999 (ferie) \\
\hline Skolegang & - ingen offentlig undervisning på/i dansk \\
\hline Udvandring & $\begin{array}{l}\text { - far fra det nordvestlige Jylland, årstal ukendt } \\
\text { - morforældre fra ? omkring 1880 }\end{array}$ \\
\hline
\end{tabular}


De fire talere er repræsentative for vores informanter og indbyrdes sammenlignelige: De har alle dansk som deres første sprog, de talte det hjemme med deres forældre, og tre af dem lærte ikke spansk før de begyndte i skole. To af dem har boet i tre år i Danmark som ganske unge, og de andre to har kun været én gang i Danmark, på ferie i 1990'erne. Også hvad angår køn afspejler de fordelingen i vores informantgruppe hvor omtrent to tredjedele er kvinder - hvilket igen nogenlunde afspejler den faktiske kønsfordeling i den arvesprogsdansktalende population i Argentina. Der er flere kvinder end mænd tilbage i den ældste generation, og derudover har flere kvinder end mænd haft interesse $\mathrm{i}$ at videregive og bevare det danske sprog, ligesom de også traditionelt i mindre grad har været i berøring med majoritetssamfundet og derfor har "kunnet klare sig" med dansk.

I de fire interview har jeg opmærket samtlige forekomster af alle typer ledsætninger med sætningsadverbial, med alle slags konjunktioner og alle slags sætningsadverbialer. ${ }^{7}$ I 75 ud af 111 sætninger er sætningsadverbialet $i k k e$, sommetider i kombination med et andet adverbial, fx jo ikke, ikke rigtig og ellers $i k k e$. Det næsthyppigste sætningsadverbial er jo med 10 forekomster (hvor det står alene). De resterende sætningsadverbialer er kun repræsenteret med tre eller færre forekomster, eksempelvis aldrig, godt, sådan, lige, nok, nu, altså, virkelig, bare, egentlig. Dernæst har jeg kategoriseret alle sætningerne i forhold til dels ledstilling, adv $>V$ - respektive $V>$ adv-ledstilling, dels syntaktisk funktion, dvs. jeg har bestemt om ledsætningerne var nominale, adverbielle eller attributive.

\section{Resultater}

\subsection{Det generelle billede}

I alt ytrer de fire talere 123 ledsætninger med sætningsadverbialer. 12 af disse udtrykker direkte citeret tanke eller tale uden indledende konjunktion, som i (5):

$(\underline{\mathrm{DOB}})$ \# men så sagde min far \# jamen jeg kan ikke bo oppe i \# urskoven

7 I denne artikel har jeg taget udgangspunkt i den liste over sætningsadverbialer som Jensen og Christensen har udarbejdet i forbindelse med deres undersøgelse, og går ikke ind i diskussionen om hvad der konstituerer et sætningsadverbial. sådan (jf. nedenfor) står ikke på denne liste, men det optræder i mine data to gange tydeligvis som talerens kommentar til det ytrede. 
Alle 12 forekomster har $\mathrm{V}>$ adv-ledstilling, og det ækvivalerer med Jensen \& Christensens (2013:48) resultater for danmarksdansk hvor der heller ikke er fundet nogen tilfælde af ledsætningsledstilling i denne kontekst. Man kan derfor regne dem for "citerede helsætninger" og derfor også uden for "the envelope of variation". Af samme grund har jeg ikke inkluderet dem i analysen.

Af de resterende 111 ledsætninger med sætningsadverbial har 34\% $(\mathrm{n}=38)$ V>adv-ledstilling. Sammenlignet med de 49 \% ledsætninger med V>advledstilling i danmarksdansk betyder det altså at der er færre helsætningsformede ledsætninger i dette udsnit af dansk i Argentina end i dansk i Danmark. Det tyder på at fordelingen - og derfor muligvis også betydningen af de to ledstillinger - er forskellig fra danmarksdansk, men vi er naturligvis nødt til at analysere meget mere data for at kunne bekræfte det.

\subsection{Resultater fordelt på ledsatningstype og konjunktional}

Alle fire talere har en meget ens fordeling af ledstilling i ledsætningerne. Jeg har derfor stablet talerne i figur 2. Søjlerne repræsenterer procentsatser, men det faktiske antal forekomster er noteret på hver søjle.

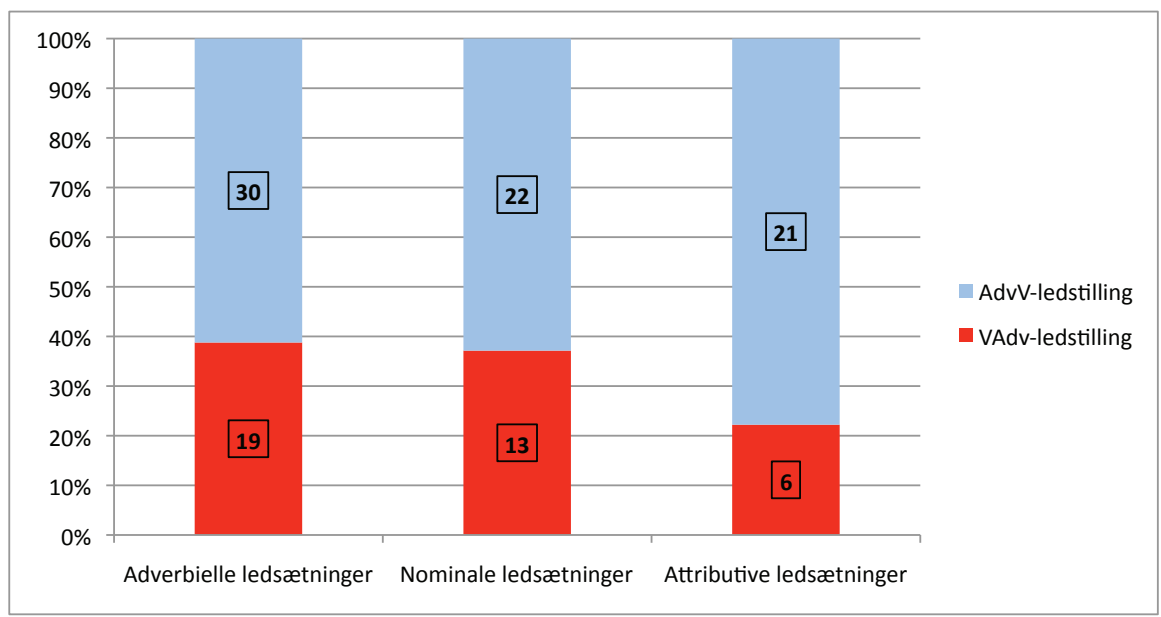

Figur 1. Ledsetninger, fordelt på type.

I grafen ovenfor ser det ud til at de adverbielle og de nominale ledsætninger har mere V>adv-ledstilling end de attributive i dansk i Argentina. Jeg har chi-i-anden-testet for at se om forskellen mellem den relativt højere andel af V>adv-ledstilling i de adverbielle og de nominale ledsætninger end i de attributive ledsætninger er statistisk signifikant. Det giver resultatet $\mathrm{p}=0,13$, og 
dermed har de attributive ledsætninger altså ikke lavere sandsynlighed for at have $\mathrm{V}>$ adv-ledstilling end de nominale og de adverbielle ledsætninger under ét. Imidlertid er de faktiske antal forekomster så fă at det formentlig ikke giver et helt retvisende billede. Et større datagrundlag er nødvendigt for at kunne sige noget om ledstillingstendensen for attributivsætningerne i forhold til de to andre typer ledsætninger.

De attributive ledsætninger ser ud til i højere grad at tillade $\mathrm{V}>$ adv-ledstilling i dansk i Argentina (med $22 \%$ ) end i dansk i Danmark (med $4 \%$, som dækker over 71 forekomster ud af i alt 1.786 attributive ledsætninger). En chi-i-anden-test kan ikke anvendes her da de seks ledsætninger med V>advledstilling i dansk i Argentina er underrepræsenterede i forhold til det øvrige antal forekomster. Med en Fisher's exact test (som dog også er behæftet med usikkerhed når tallene er så små), får man resultatet $p=0,0007$. Det giver således en statistisk begrundet hypotese om at de attributive ledsætninger $\mathrm{i}$ dansk i Argentina har en højere sandsynlighed for at have V>adv-ledstilling end de attributive ledsætninger i danmarksdansk. Det vil vise sig om resultatet holder når vi analyserer et større datasæt.

Når man ser på konjunktionerne i de adverbielle og de nominale ledsætninger, er fordelingen meget lig den man finder i danmarksdansk (jf. afsnit 2.1.). Blandt de 19 adverbielle ledsætninger med $V>$ adv-ledstilling har 14 konjunktionen fordi, mens de nominale ledsætninger med $\mathrm{V}>$ adv-ledstilling alle er indledt af enten at ( 7 forekomster) eller ingen konjunktion (6 forekomster). Det lader altså til at være de samme konjunktioner eller udeladelsen af dem der giver øget tendens til $\mathrm{V}>$ adv-ledstilling i nominale og adverbielle ledsætninger i dansk i Argentina som i dansk i Danmark.

\subsection{Ledstilling $i$ ledscetninger $i$ dansk $i$ Argentina versus $i$ norsk og svensk $i$ USA}

Sammenholder man resultaterne med Larsson \& Johannessens konklusioner, kan man konstatere at vi også finder V>adv-ledstilling i alle typer af ledsætninger. Dog lader valget af ledstilling ikke til at være valgfrit i dansk i Argentina: For det første er der stadig samlet set en præference for adv $>V$ ledstilling som endda for de nominale og de adverbielle ledsætninger er større end i moderne danmarksdansk talesprog. For det andet ser der også ud til at være en meget klar korrelation mellem $\mathrm{V}>$ adv-ledstilling og visse konjunktioner (præcis som i danmarksdansk).

Larsson \& Johannessen argumenterer for at V>adv-ledstillingen er uafhængig af ledsætningstype. Mit casestudie kunne ikke vise at de attributive 
ledsætninger havde signifikant lavere sandsynlighed for $\mathrm{V}>$ adv-ledstilling end de nominale og de adverbielle, og dermed kan vi foreløbig ikke afvise en tilsvarende typeuafhængighed i dansk i Argentina.

$\mathrm{Vi}$ er ikke endegyldigt i stand til at sige om en forandring har fundet sted i syntaksen i forhold til de danske udvandreres 'baselinesprog', svarende til Larsson \& Johannessens udlægning af deres resultater. Ikke desto mindre ved vi at der i udvandringsårene har været dialektal variation - og formentlig også i standardlignende talesprog - i forhold til ledstilling (Pedersen 1996, Gregersen \& Pedersen 2000). Derfor ville der formentlig ikke kunne være tale om samme drastiske forandring i arvedansk som den Larsson \& Johannessen argumenterer for har fundet sted i arvesvensk- og norsk. Vi ved endnu ikke med sikkerhed hvilken rolle 'afbrudt tilegnelse' spiller i produktionen af ledsætninger i dansk i Argentina.

\section{Diskussion og afrunding}

På baggrund af det foreliggende casestudie antager jeg at andelen af $\mathrm{V}>\mathrm{adv}$ ledstilling måske nok er lidt lavere i dansk i Argentina samlet set, men også at korrelationen mellem konjunktionstype og $\mathrm{V}>$ adv-ledstilling i nominale og adverbielle ledsætninger ikke er afgørende anderledes end den man finder i moderne danmarksdansk talesprog idet det fortrinsvis var de fire taleres fordiog at-sætninger og sætninger uden konjunktion der havde $\mathrm{V}>$ adv-ledstilling. De attributive ledsætninger udviser i nærværende studium en signifikant afvigelse i ledstillingsfordelingen fra danmarksdansk. Samtidig viste det sig at være statistisk tilfældigt at der var relativt færre attributive end nominale og adverbielle ledsætninger med V>adv-ledstilling. Det vil være en markant og interessant forskel fra danmarksdansk hvis det ved inddragelse af mere data fortsat viser sig at de attributive faktisk har en lige så høj andel af V>advledstilling som de to andre typer ledsætninger. Dette casestudie afføder et brugbart hypotesegrundlag for videre studier af ledstilling i ledsætninger i dansk i Argentina.

Når det kommer til betydningen af hhv. den ene og den anden ledstilling i dansk i Argentina, har vi endnu ikke noget bud. Jeg har endnu ikke analyseret sætningerne i mine data for at se hvad det betyder - eller om det overhovedet betyder noget - at bruge $\mathrm{V}>$ adv-ledstilling. Man kan sagtens forestille sig at den danmarksdanske semantiske distinktion mellem ledstillingerne er brudt sammen, eller at den måske aldrig har fungeret på den måde i dansk i Argentina. De udvandrerefterkommere der taler dansk i Argentina i dag, 
har arvet et dansk i hvilket distinktionen muligvis endnu ikke var etableret (Gregersen \& Pedersen 2001).

Som det fremgik af afsnit 2.1., er de ældste informanter i Jensen \& Christensens studium af ledstilling i ledsætninger i talt dansk i Danmark født i 1942, og det er endog kun et udsnit af de 91 informanter. Når det alligevel synes rimeligt at sammenligne de fire dansk-argentinske informanter (født $\mathrm{ml}$. 1921 og 1935) i dette casestudie med resultaterne af det store danske studium, er det fordi Jensen \& Christensen finder at distinktionen mellem adv $>\mathrm{V}-\mathrm{og}$ V>adv-ledstilling i talesprog først og fremmest er betinget af sproglige faktorer, ikke af de sociale variabler (Jensen \& Christensen 2013:54, Christensen, Jensen \& Christensen 2015:113).

Sammenholdt med Larsson \& Johannessens undersøgelse af svensk og norsk i USA, kan man sige at dette casestudie umiddelbart peger på at der ikke er valgfri ledstillingsbrug i ledsætninger i dansk i Argentina. Der er en overordnet præference for $\mathrm{adv}>\mathrm{V}$-ledstilling, ligesom også selve konjunktionstypen lader til at være afgørende. Om ledstillingsbrugen er uafhængig af ledsætningstype, vil analyser af flere attributive ledsætninger i høj grad være med til at kaste lys over.

Skønt vi ikke ved præcis i hvor høj grad anvendelsen af V>adv-ledstilling er et spørgsmål om afbrudt tilegnelse af systemet, mener jeg ikke at det kan bruges som - eller i hvert fald ikke stå alene som - forklaring. Det vægtigste argument herimod er at baseret på dette studium har dansktalere i Danmark en højere andel af ledsætninger med V>adv-ledstilling end dansktalere i Argentina, og man må gå ud fra at tilegnelsen for talere i Danmark med dansk som deres første og primære sprog ikke har været afbrudt, og at de har tilegnet sig den ledstillingssyntaktiske struktur fuldstændigt.

Det er relevant at sætte spørgsmålstegn ved den overordnede sammenlignelighed mellem mit og Larsson \& Johannessens studier: For det første undersøger de kun ledsætninger med visse konjunktioner og kun med $i k k e$ som sætningsadverbial. For det andet er Larsson \& Johannessens udgangspunkt et andet end udgangspunktet for et studium af ledstilling i ledsætninger i enhver varietet af dansk. Vi ved at der er - og længe har været - meget stor variation på dette punkt i dansk i Danmark, mens der for svensk og norsk ikke er blevet lavet nogen store undersøgelser af fænomenet i talesprog. Det som Larsson \& Johannessen kalder en forandring i grammatikken i svensk og norsk i USA svarer til omtrent den samme andel V>adv-ledstilling i ledsætninger i talt dansk i Danmark. Den forandring de taler om, kan vise sig slet ikke at være en forandring. 
Perspektiverne for videre studier er mange. Foruden de allerede nævnte er aspekter som sætningens informationsstatus, type af oversætningsprædikat, adverbialtype, ledsætningens placering i oversætningen, ledsætningens længde og ledsætningens integrering i oversætningen ${ }^{8}$ mere eller mindre essentielle at have med i en analyse af ledstilling i ledsætninger.

Et forsøg på at indkredse årsagen til et givent ledstillingsmønster i dansk i Argentina vil også stå centralt i de videre studier. Her vil jeg vende blikket mod ledstillingen i det omgivende majoritetssprog og se på om transfer fra spansk kan have været med til at tegne mønsteret i det danske arvesprog. Spansk har langt videre muligheder når det kommer til placeringen af sætningsadverbialer i sætningen, men der er én undtagelse: Negationen no 'ikke' står altid umiddelbart før verbalet, fx:

$\begin{array}{lllll}\text { K } & \text { S } & \text { SA } & \text { V } & (\text { FV } / F A) \\ \text { que } & \text { (él) } & \text { no } & \text { comió } & \text { pasta ayer }\end{array}$

Denne ledstilling svarer, som det fremgår, til det danske 'ledsætningsskema', og man kan antage at placeringen af $n o$ i spansk virker stabiliserende for netop denne ledstilling i ledsætninger i dansk i Argentina - eller i hvert fald når sætningsadverbialet er ikke. Mit casestudie har foreløbig påvist en præference for $\mathrm{adv}>\mathrm{V}$-ledstilling i sætninger med alle typer sætningsadverbialer, og det vil være interessant at undersøge om det særligt gælder sætninger med ikke. Hvis det desuden viser sig at ledsætningerne med ikke har en højere andel af $a d v>V$-ledstilling end fx dansk i USA (som bliver udforsket som en del af 'Danske Stemmer'-projektet) vil det yderligere kunne slå fast at kontaktsproget faktisk spiller en rolle for dansk i Argentina. Desuden vil det pege på at arvesprogene måske ikke er så ens endda i deres udvikling (i så fald ville Larsson \& Johannessen finde en lignende effekt), og at man er nødt til at tage en lang række sprog- og kontekstspecifikke træk med i betragtningen når man analyserer arvesprog.

8 Det er ikke alle disse faktorer der er lige relevante endsige analyserbare for alle tre typer af ledsætninger; således har fx sætningens informationsstatus og type af oversætningsprædikat kun relevans for ledsætninger som er styret af et prædikat i oversætningen, dvs. de nominale, mens det kun er væsentligt at undersøge hvor tæt knyttet ledsætningen er til sin oversætning for de adverbielle ledsætninger (jf. 'ledsætningens integrering i oversætningen'). 


\section{Henvisninger}

Arnbjörnsdóttir, B. (2015). Reexamining Icelandic as a heritage language in North America, i J.B. Johannessen \& J.C. Salmons (red.) Germanic Heritage Languages in North America: Acquisition, attrition and change, Amsterdam/Philadelphia: John Benjamins, 72-93.

Benmamoun, E., S. Montrul \& M. Polinsky (2013). Heritage languages and their speakers: Opportunities and challenges for linguistics, i M. Krifka (red.) Theoretical Linguistics. Berlin/New York: de Gruyter Mouton, 129-181.

Christensen, T.K., T.J. Jensen \& M.H. Christensen (2015). Adverbielle ledsætningers ledstilling i dansk talesprog, i I.S. Hansen \& T.T. Hougaard (red.) MUDS - Møderne om Udforskningen af Dansk Sprog 15, Aarhus: Institut for Kommunikation og Sprog, Aarhus Universitet, 97-115.

Christensen, T.K. \& T.J. Jensen (2014a). Sætningsadverbialer i ledsætninger som forgrundssignal, i M. Birkelund, et al. (red.) Ny forskning i grammatik 21, Odense: Syddansk Universitetsforlag, 37-53.

Christensen, T.K. \& T.J. Jensen (2014b). Det er klart at ledsætninger har da ledsætningsordstilling - eller har de?, Nyt fra Sprognaunet 2014/1, 1-7.

Eide, K.M. \& A. Hjelde (2015). Verb Second and Finiteness Morphology in Norwegian Heritage Language of the American Midwest, i R.S. Page \& M.T. Putnam (red.), Moribund Germanic Heritage Languages in North America: Theoretical Perspectives and Empirical Findings, Leiden/Boston: Brill Academic Publishers, 153-189.

Flodell, G. (1996). Immigrant Swedish in Misiones, Argentina - towards language loss, i P.S. Ureland \& I. Clarkson (red.), Language contact across the North Atlantic, Tübingen: Niemeyer, 217-235.

Gregersen, F. \& I.L. Pedersen (2000). A la Recherche du Word Order Not Quite Perdu, i S.C. Herring, P.T.v. Reenen \& L. Schøsler (red.) Textual Parameters in Older Languages, Amsterdam/Philadelphia: John Benjamins, 393-431.

Heltoft, L. (1999). Hierarki og rækkefølge - skandinavisk ledstilling i funktionel grammatisk belysning, i P.A. Jensen \& P. Skadhauge (red.) Satningsskemaet i generativ grammatik, Kolding: Institut for Erhvervssproglig Informatik og Kommunikation, Syddansk Universitet, 31-62.

Jensen, T.J. \& T.K. Christensen (2013). Promoting the demoted: The distribution and semantics of "main clause word order" in spoken Danish complement clauses, Lingua 137, 38-58.

Jensen, T.J. (201 1). Ordstilling i ledsætninger i moderne dansk grammatik, i P. Durst-Andersen \& H.H. Müller (red.) Ny forskning i grammatik 18, Odense: Syddansk Universitet, 123-150. 
Kaufman, G. (2010). Non-convergence despite language contact, i P. Auer \& J.E. Schmidt (red.), Language and Space: Theories and Methods, Berlin: De Gruyter Mouton, 478-493.

Kühl, K. (2014). 'Det er easy at tale engelsk også'. Amerikadansk i 1960'erne og 1970'erne, NyS 47, 39-64.

Larsson, I. \& J.B. Johannessen (2015a). Incomplete Acquisition and Verb Placement in Heritage Scandinavian, i R.S. Page \& M.T. Putnam (red.), Moribund Germanic Heritage Languages in North America: Theoretical Perspectives and Empirical Findings, Leiden/Boston: Brill, 153-189.

Larsson, I. \& J.B. Johannessen (2015b). Embedded word order in Heritage Scandinavian, i M. Hilpert et al. (red.) New Trends in Nordic and General Linguistics, Berlin: Mouton de Gruyter, 239-267.

Pedersen, I.L. (1996). 'Der kan jo være nogen der kan itte tåle det': Om hovedsætningsordstilling i bisætninger i danske dialekter, i B.J. Nielsen \& I.L. Pedersen (red.) Studier i talesprogsvariation og sprogkontakt: Festskrift til Inger Ejskjar, København: C.A. Reitzel, 242-251.

Polinsky, M. (2011). Reanalysis in adult heritage language: A case for attrition, Studies in Second Language Acquisition 33, 305-328.

Polinsky, M. \& O. Kagan, O. (2007). Heritage Languages: In the 'Wild' and in the Classroom, Languages and Linguistics Compass 1(5), 386-295. 